\title{
PENGARUH TEMPERATUR AGING TERHADAP PADUAN ALUMUNIUM SERI 6069 TERHADAP NILAI KEKERASAN DAN KEKUATAN IMPACT
}

\author{
Oleh \\ Wisnaningsih dan M. Yunus \\ Dosen Tetap pada Program Studi Teknik Mesin \\ Fakultas Teknik Universits Sang Bumi Ruwa Jurai (Lampung - Indonesia)
}

\begin{abstract}
Abstrak
Alumunium adalah logam yang memiliki kekuatan relatif rendah dan lunak. Alumunium juga dikenal memiliki ketahanan korosi yang cukup tinggi terhadap udara, air, oli, beberapa larutan kimia dan sebagai konduktor listik yang cukup baik. Pada umumnya Alumunium dicampur dengan unsur logam lain sehingga membentuk Alumunium paduan diantaranya adalah tembaga, silicon, magnesium. Dengaan penambahan unsure tersebut, Alumunium dapat memilki kekuatan 83-310 Mpa, dan melalui proses perlakuan panas peningkatan kekuatan pada alumunium paduan dapat mencapai lebih dari $700 \mathrm{Mpa}$.

Proses perlakuan panas tersebut dikenal dengan proses pengerasan presipitasi,dimana salah satu langkahnya adalah proses Aging. Proses pengerasan presipitasi ini menyangkut lakupelarutan, diawali dengan proses pemanasan awal dilanjutkan dengan pencelupan atau pendinginan secara cepat, sering disebut quenching sehingga terjadi larutan padat lewat jenuh. Setalah pencelupan, paduan dipanaskan kembali (aging) sampai temperatur tertentu dimana presipitasi mulai terbentuk setelah selang waktu tertentu. Atom lewat jenuh cenderung berhimpun dalam bidang-bidang kristal tertentu.

Pengerasan dislokasi melalui batas yang terdistorsi. Ini sangat sulit, akibatnya logam bertambah keras dan tahan terhadap tegangan deformasi. Dari hasil pengujian terhadap alumunium paduan seri 6069 dengan parameter temperatur, peningkatan kekerasan maksimum terdapat pada temperatur $185{ }^{\circ} \mathrm{C}$ dengan kekerasan 58 HRE. Untuk peningkatan minimum terdapat pada temperatur $165{ }^{\circ} \mathrm{C}$ dengan kekerasan 47,6 HRE, dimana kekerasan alumunium dasar sebesar 28 HRE. Sedangkan untuk kekuatan impact, peningkatan maksimum terdapat pada temperatur $175^{\circ} \mathrm{C}$ dengan kekuatan impact sebesar 97 joule dan peningkatan minimum terdapat pada temperatur $185{ }^{\circ} \mathrm{C}$ dengan kekuatan impact sebesar 78,67 joule. Dimana kekuatan impact alumunium dasar 66 joule.
\end{abstract}

Kata kunci: pengaruh temperatur aging, kekerasan, kekuatan, impak alumunium

\author{
EFFECT OF AGING TEMPERATURE ON ALUMINUM ALLOY \\ 6069 SERIES ON VALUE OF VIOLENCE STRENGTH AND IMPACT \\ By \\ Wisnaningsih and M. Yunus \\ Permanent Lecturers of Mechanical Engineering Study Program \\ Engineering Faculty of Sang Bumi Ruwa Jurai University (Lampung - Indonesia)
}

Abstact

Aluminum is a metal that has a relatively low strength and soft. Aluminum is also known to have a sufficiently high corrosion resistance to air, water, oil, some chemical solution and as a fairly good electric conductors. In general, aluminum mixed with other metals to form aluminum alloys include copper, silicon, magnesium. Digitally addition of these elements, 
aluminum can have the strength of 83-310 Mpa, and through a process of heat treatment on the aluminum alloy increased strength can reach more than $700 \mathrm{Mpa}$.

The heat treatment process known as precipitation hardening process, in which one of the steps is the process of Aging. The precipitation hardening process involves behaviordissolution, beginning with the initial heating process followed by immersion or rapid cooling, often called quenching resulting in a supersaturated solid solution. After dyeing, the alloy is heated again (aging) up to a certain temperature where precipitation begins to form after a certain time interval. Atom superheated tends to gather in certain areas of the crystal.

Hardening dislocations through the boundary distorted. It's very difficult, resulting in increased metal hard and resistant to deformation voltage. From the test results of 6069 series aluminum alloys with temperature parameters, increase the maximum hardness are at a temperature of $185{ }^{\circ} \mathrm{C}$ with $58 H R E$ violence. For there is a minimum increase in temperature of $165^{\circ} \mathrm{C}$ with 47,6HRE violence, where violence by 28 HRE aluminum base. As for the impact strength, the maximum increase in temperatures are $175{ }^{\circ} \mathrm{C}$ with an impact strength of 97 joules and there is a minimum increase in temperature of $185^{\circ} \mathrm{C}$ the impact strength of 78.67 joules. Where the impact strength of the aluminum base 66 joules.

Keywords: effect of temperature aging, violence, strength, impact aluminum.

\section{PENDAHULUAN}

\subsection{Latar Belakang}

Berdasarkan penelitian sebelumnya pada Alumunium, didapatkan temperatur untuk pemanasan awal sebesar $550{ }^{\circ} \mathrm{C}$ dan penahanan selama 30 menit, quenching dengan menggunakan air, dan aging pada temperatur $175{ }^{\circ} \mathrm{C}$ selama 10 jam (Murayama, 2002). Logam Alumunium memiliki titik cair sekitar $\quad 660 \quad{ }^{\circ} \mathrm{C} \quad$ sehingga memungkinkan untuk dilakukan proses pengerasan presipitasi melalui temperatur Aging dan dalam proses ini akan diketahui berapa besar paduan Alumunium seri 6069 mendapatkan nilai kekerasan dan kekuatan impak yang semakin baik jika dibandingkan dengan base material (bahan dasar).

Peningkatan kekuatan pada paduan Alumunium dapat dilakukan melalui proses pengerjaan dingin dan melalui perlakuan panas yang dikenal dengan proses pengerasan presipitasi, dimana salah satu langkahnya adalah proses Aging.

Karena belum adanya temperatur yang optimum untuk peningkatan kekuatan sifat mekanik pada paduan Alumunium seri 6069, maka pada penelitian ini akan diujikan tiga parameter temperatur aging yaitu $165^{\circ} \mathrm{C}, 175^{\circ} \mathrm{C}, 185^{\circ} \mathrm{C}$ dengan waktu penahanan aging 2 jam. 


\section{LANDASAN TEORI}

\subsection{Bahan dan Alat Penelitian}

\section{Bahan Penelitian ;}

1. Logam Alumunium paduan Seri 6069.

\section{Alat Penelitian ;}

1. Mesin METACUT (Potong).

Mesin ini digunakan untuk memotong bahan

2. Mesin Sekrap.

Mesin ini digunakan untuk pembentukan spesimen.
3. Tungku (furnace).

Alat yang digunakan untuk proses perlakuan panas.

4. Hardness test.

Alat pengujian kekerasan untuk mengetahui kekerasan permukaan Alumunium.

5. Impact Test.

Alat pengujian untuk mengetahui kekuatan beban kejut pada Alumunium.

\subsection{Diagram Alur Penelitian}

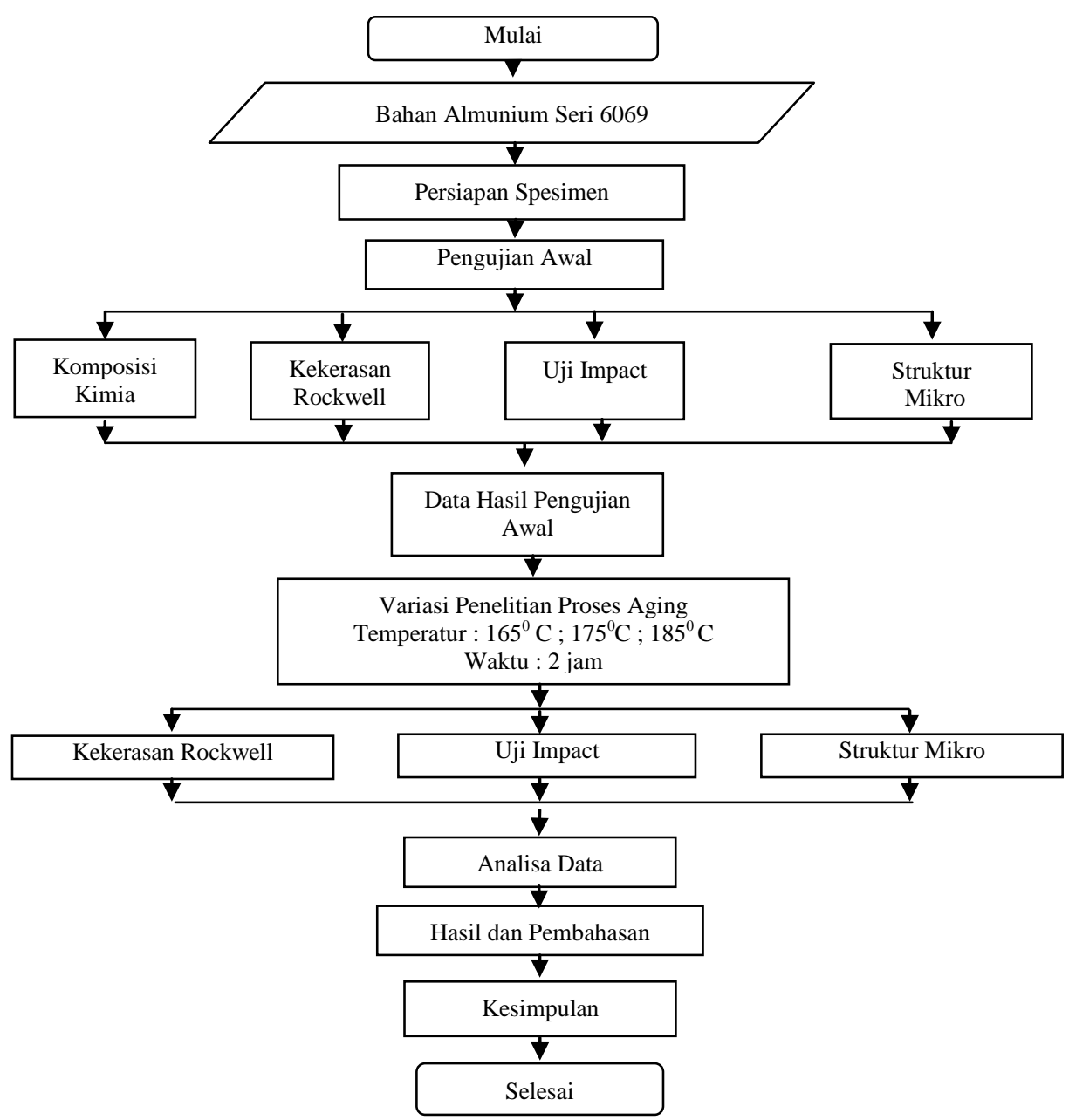

Gambar 1. Diagram Alir 
III HASIL DAN PEMBAHASAN

\subsection{Hasil Pengujian Komposisi}

Pengujian ini dilakukan untuk mengetahui komposisi kimia yang terkandung didalam bahan sebelum dilakukan pengujian-pengujian yang lain. Nilai komposisi yang terdapat dalam bahan dapat dilihat dalam tabel 1 .

Tabel:1 Komposisi Kimia Alumunium Seri 6069

\begin{tabular}{|c|c|c|}
\hline No & Kandungan Kimia & $\mathbf{( \% )}$ \\
\hline $\mathbf{1}$ & $\mathbf{S i}$ & 1.0286 \\
\hline $\mathbf{2}$ & $\mathbf{M g}$ & 1.6366 \\
\hline $\mathbf{3}$ & $\mathbf{C r}$ & 0.6296 \\
\hline $\mathbf{4}$ & $\mathbf{M n}$ & 0.0514 \\
\hline $\mathbf{5}$ & $\mathbf{V}$ & 0.2093 \\
\hline $\mathbf{6}$ & $\mathbf{C u}$ & 0.1235 \\
\hline $\mathbf{7}$ & $\mathbf{T i}$ & 0.0086 \\
\hline $\mathbf{8}$ & $\mathbf{A l}$ & 96.1333 \\
\hline $\mathbf{9}$ & $\mathbf{S r}$ & 0.0127 \\
\hline $\mathbf{1 0}$ & $\mathbf{Z n}$ & 0.1638 \\
\hline $\mathbf{1 1}$ & $\mathbf{F e}$ & 0.0026 \\
\hline
\end{tabular}

Sumber : Data Primer

\subsection{Pengujian Kekerasan}

Pengujian kekerasan ini dilakukan dengan mengambil lima titik pada masing-masing spesimen. Nilai tersebut dirata-ratakan dan didapat nilai kekerasan rata-rata dari setiap spesimen.

\section{Nilai Kekerasan Pada Spesimen}

\section{Bahan Dasar}

Pada bahan dasar hasil nilai

kekerasan setiap titik dan nilai rata-ratanya dapat dilihat pada tabel 2 dibawah ini:

Tabel 2. Hasil Pengujian Kekerasan Base Metal

\begin{tabular}{|c|c|c|c|c|c|c|c|}
\hline \multirow{2}{*}{ No } & \multirow{2}{*}{ Bahan } & \multicolumn{5}{|c|}{ Nilai Kekerasan Tiap Titik (HRE) } & \multirow{2}{*}{$\begin{array}{l}\text { Nilai } \\
\text { Rata- } \\
\text { rata }\end{array}$} \\
\hline & & Titik 1 & Titik 2 & Titik 3 & Titik 4 & Titik 5 & \\
\hline 1. & Base Metal & 26 & 28 & 28 & 29 & 29 & 28 \\
\hline
\end{tabular}

Dari tabel diatas menunjukkan nilai kekerasan pada titik 1 sebesar 26 HRE, pada titk 2 sebesar 28 HRE, pada titk 3 sebesar 28 HRE, pada titk 4 sebesar 29 HRE, dan pada titik 5 sebesar 29 HRE. Nilai tersebut dapat dibuat dalam grafik yang menggambarkan tingkat kekerasan bahan dasar dalam tiap titik. 


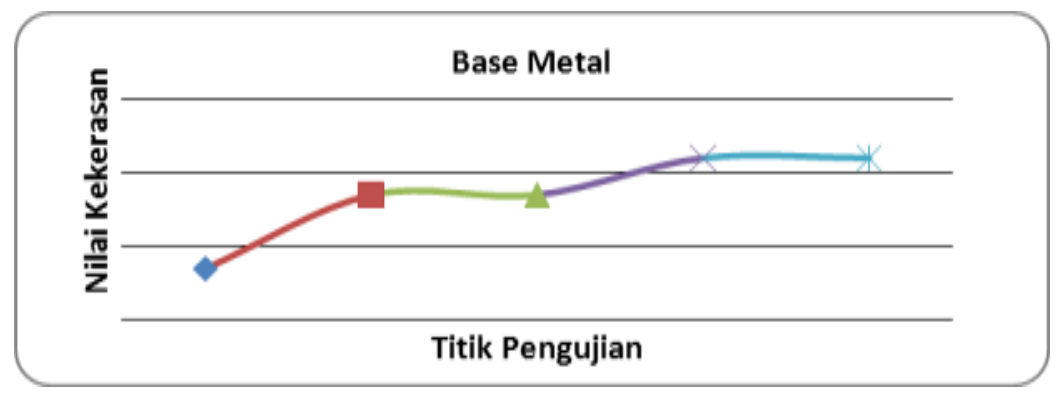

Gambar 2. Grafik Nilai Kekerasan Bahan Dasar

\section{Kekerasan Pada Spesimen}

\section{Temperatur $165^{\circ}$}

Pada spesimen temperatur $165^{0}$

hasil nilai kekerasan setiap titik dan nilai rata-ratanya dapat dilihat pada tabel 3 dibawah ini :

Tabel 3. Hasil Pengujian Kekerasan Temperatur $165{ }^{\circ} \mathrm{C}$

\begin{tabular}{|c|c|c|c|c|c|c|c|}
\hline \multirow{2}{*}{ No } & \multirow{2}{*}{ Bahan } & \multicolumn{5}{|c|}{ Nilai Kekerasan Tiap Titik (HRE) } & \multirow{2}{*}{$\begin{array}{c}\text { Nilai } \\
\end{array}$} \\
\cline { 3 - 8 } & & Titik 1 & Titik 2 & Titik 3 & Titik 4 & Titik 5 & Rata-rata \\
\hline 1 & Temperatur $165^{\circ} \mathrm{C}$ & 47 & 46 & 48 & 49 & 48 & 47.6 \\
\hline
\end{tabular}

Dari tabel diatas menunjukkan

nilai kekerasan temperatur $165^{\circ}$

pada titik 1 sebesar $47 \mathrm{HRE}$, pada

titk 2 sebesar $46 \mathrm{HRE}$, pada titk 3

sebesar 48 HRE, pada titk 4

sebesar 49 HRE, dan pada titik 5 sebesar 48 HRE. Nilai tersebut dapat dibuat dalam grafik yang menggambarkan tingkat kekerasan bahan dasar dalam tiap titik.

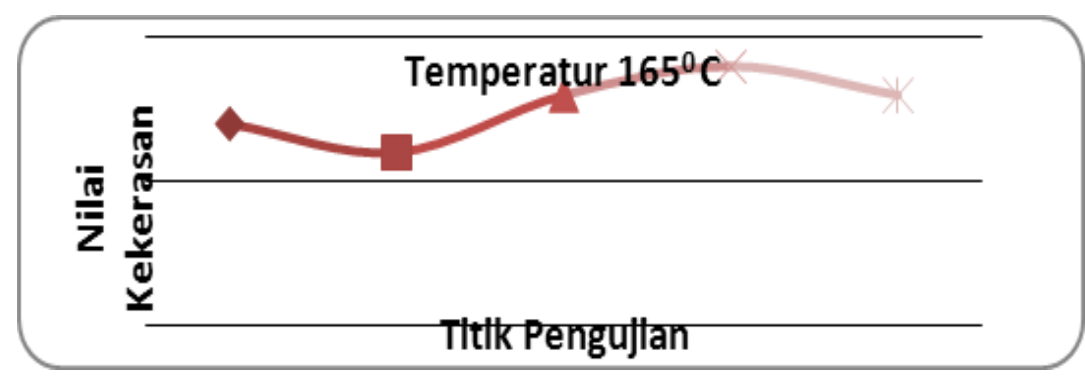

Gambar 3. Grafik Nilai Kekerasan Temperatur $165^{\circ} \mathrm{C}$

3. Nilai Kekerasan Pada Spesimen

Temperatur $175^{\circ} \mathrm{C}$

Pada spesimen temperatur $175^{\circ} \mathrm{C}$

hasil nilai kekerasan setiap titik dan nilai rata-ratanya dapat dilihat pada tabel 4 dibawah ini : 
Tabel 4. Hasil Pengujian Kekerasan Temperatur $175^{\circ} \mathrm{C}$

\begin{tabular}{|c|c|c|c|c|c|c|c|}
\hline \multirow{2}{*}{ No } & \multirow{2}{*}{ Bahan } & \multicolumn{4}{|c|}{ Nilai Kekerasan Tiap Titik (HRE) } & Nilai \\
\cline { 3 - 7 } & & Titik 1 & Titik 2 & Titik 3 & Titik 4 & Titik 5 & $\begin{array}{c}\text { Rata } \\
\text { rata }\end{array}$ \\
\hline 1 & Temperatur $175^{\circ} \mathrm{C}$ & 54 & 57 & 58 & 55 & 57 & 56.2 \\
\hline
\end{tabular}

Dari tabel diatas menunjukkan

nilai kekerasan spesimen temperatur $175^{\circ} \mathrm{C}$ pada titik 1 sebesar 54 HRE, pada titk 2 sebesar 57 HRE, pada titk 3 sebesar 58 HRE, pada titk 4 sebesar 55 HRE, dan pada titik 5 sebesar 57 HRE. Nilai tersebut dapat dibuat dalam grafik yang menggambarkan tingkat kekerasan bahan dasar dalam tiap titik.

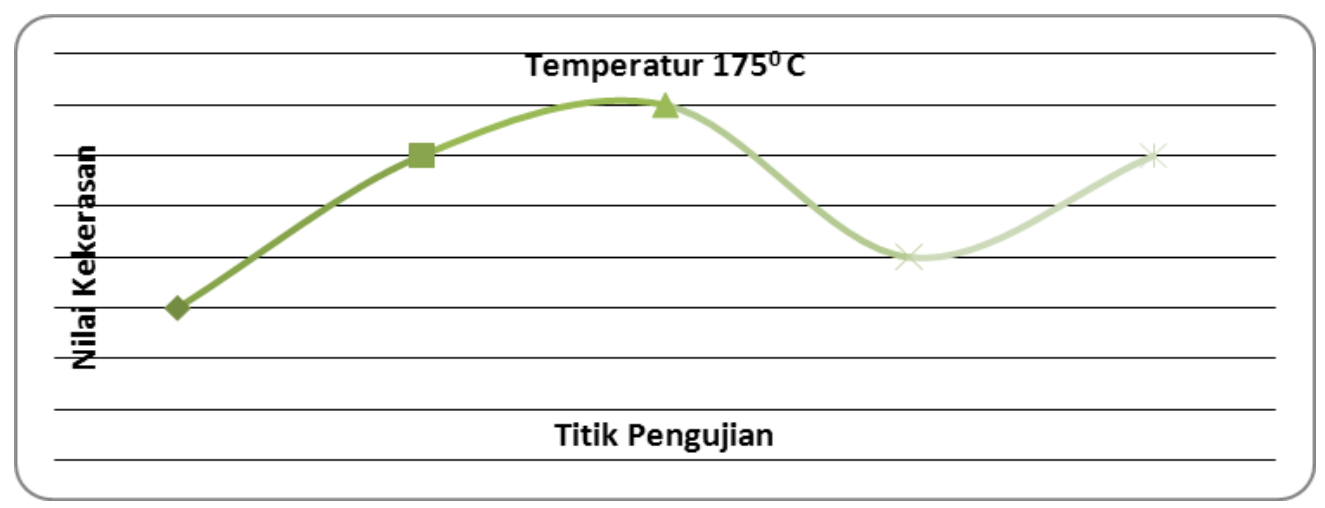

Gambar 4. Grafik Nilai Kekerasan Temperatur $175^{\circ} \mathrm{C}$

4. Nilai Kekerasan Pada

Spesimen Temperatur $185^{\circ} \mathrm{C}$

Pada spesimen temperatur $185^{\circ} \mathrm{C}$

hasil nilai kekerasan setiap titik dan nilai rata-ratanya dapat dilihat pada tabel 5 dibawah ini :

Tabel 5. Hasil Pengujian Kekerasan Temperatur $185^{\circ} \mathrm{C}$

\begin{tabular}{|c|c|c|c|c|c|l|l|}
\hline \multirow{2}{*}{ No } & \multirow{2}{*}{ Bahan } & \multicolumn{5}{|c|}{ Nilai Kekerasan Tiap Titik (HRE) } & Nilai \\
\cline { 3 - 8 } & & Titik 1 & Titik 2 & Titik 3 & Titik 4 & Titik 5 & Rata-rata \\
\hline 1 & Temperatur $185^{\circ} \mathrm{C}$ & 58 & 57 & 58 & 59 & 58 & 58 \\
\hline
\end{tabular}

Dari tabel diatas menunjukkan

nilai kekerasan spesimen temperatur $185^{\circ} \mathrm{C}$ pada titik 1 sebesar 58 HRE, pada titk 2 sebesar 57 HRE, pada titk 3 sebesar 58 HRE, pada titk 4 sebesar 59 HRE, dan pada titik 5 sebesar 58/ HRE. Nilai tersebut 


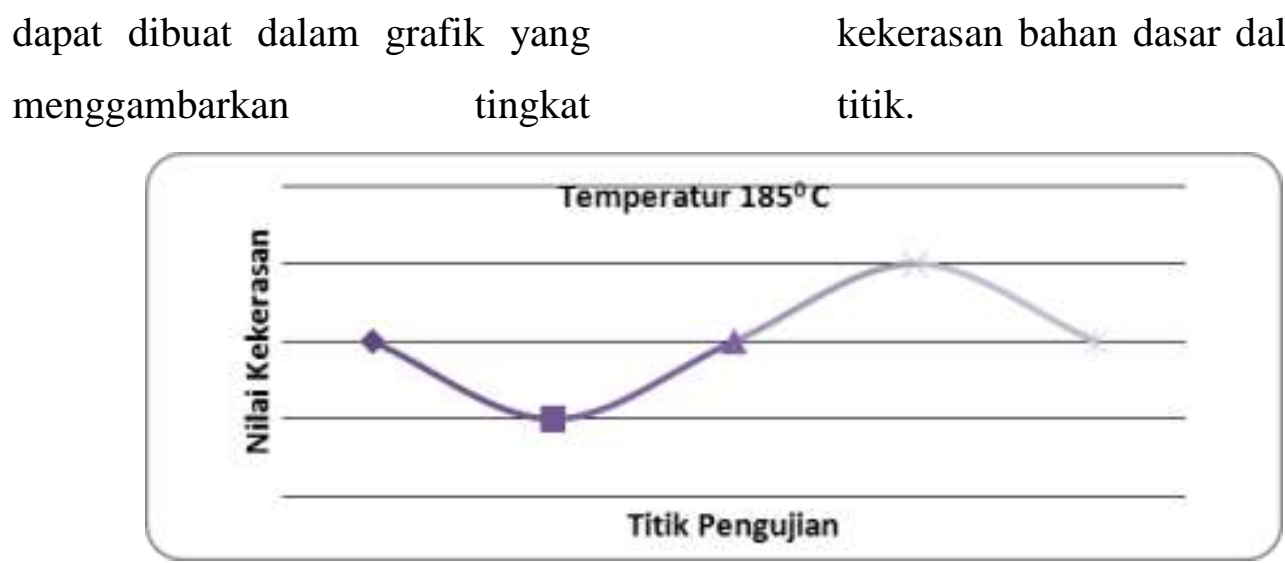

Gambar 5. Grafik Nilai Kekerasan Temperatur $185^{\circ} \mathrm{C}$

Berdasarkan nilai kekerasan setiap titik menggambarkan perubahan nilai pada tiap spesimen diatas didapat nilai kekerasan paduan alumunium seri 6069 rata-rata dan dibuatkan grafik guna setelah mengalami Proses Aging.

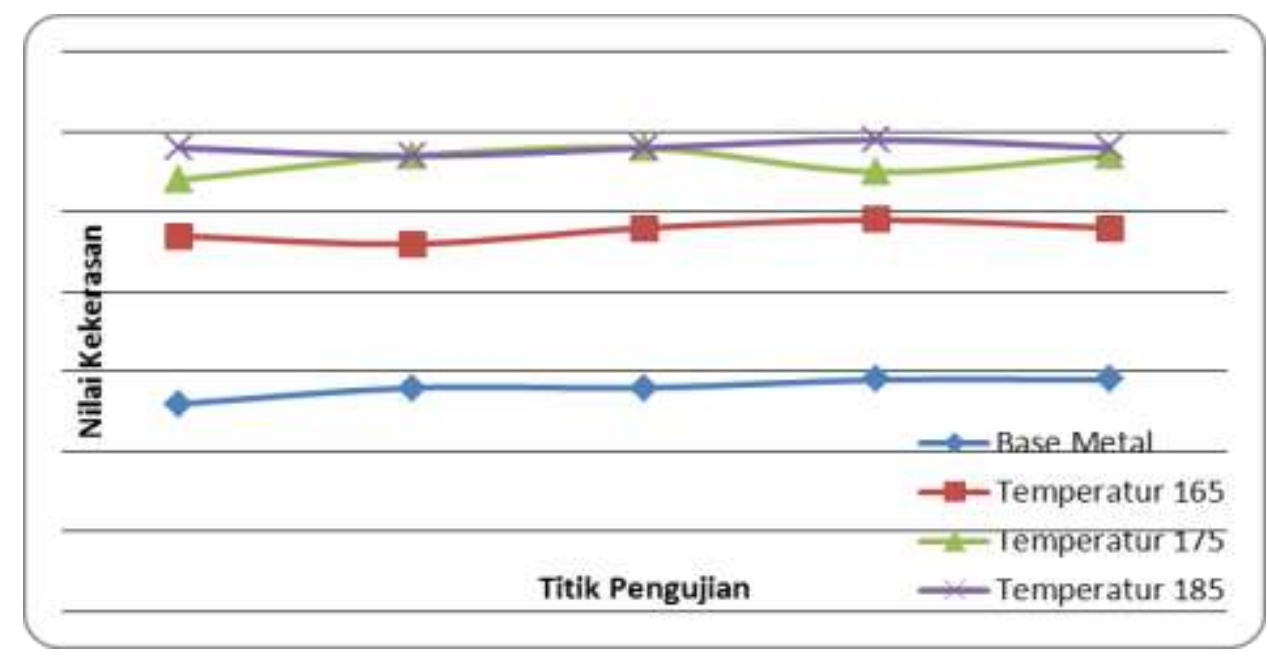

Gambar 6. Grafik Perbandingan Nilai Kekerasan Material Uji

Berikut ini table nilai kekerasan dari seluruh pengujian kekerasan yang disatukan untuk perbandingan niali kekerasan akibat pengaruh temperatur Anging.

Tabel 6. Hasil Pengujian Kekerasan Dengan Temperatur

\begin{tabular}{|c|c|c|c|c|c|c|c|}
\hline \multirow{2}{*}{ No } & \multirow{2}{*}{ Bahan } & \multicolumn{5}{|c|}{ Nilai Kekerasan Tiap Titik (HRE) } & \multirow{2}{*}{$\begin{array}{c}\text { Nilai } \\
\text { Rata- } \\
\text { rata }\end{array}$} \\
\cline { 3 - 7 } & & Titik 1 & Titik 2 & Titik 3 & Titik 4 & Titik 5 & 28 \\
\hline 1 & Base Metal & 26 & 28 & 28 & 29 & 29 & 29 \\
\hline 2 & Temperatur $165^{\circ} \mathrm{C}$ & 47 & 46 & 48 & 49 & 48 & 47.6 \\
\hline 3 & Temperatur $175^{\circ} \mathrm{C}$ & 54 & 57 & 58 & 55 & 57 & 56.2 \\
\hline 4 & Temperatur $185^{\circ} \mathrm{C}$ & 58 & 57 & 58 & 59 & 58 & 58 \\
\hline
\end{tabular}


Berdasarkan tabel diatas, terdapat nilai rata-rata dan dibuatkan grafik guna menggambarkan perubahan nilai kekerasan paduan alumunium seri 6069 setelah mengalami proses aging.

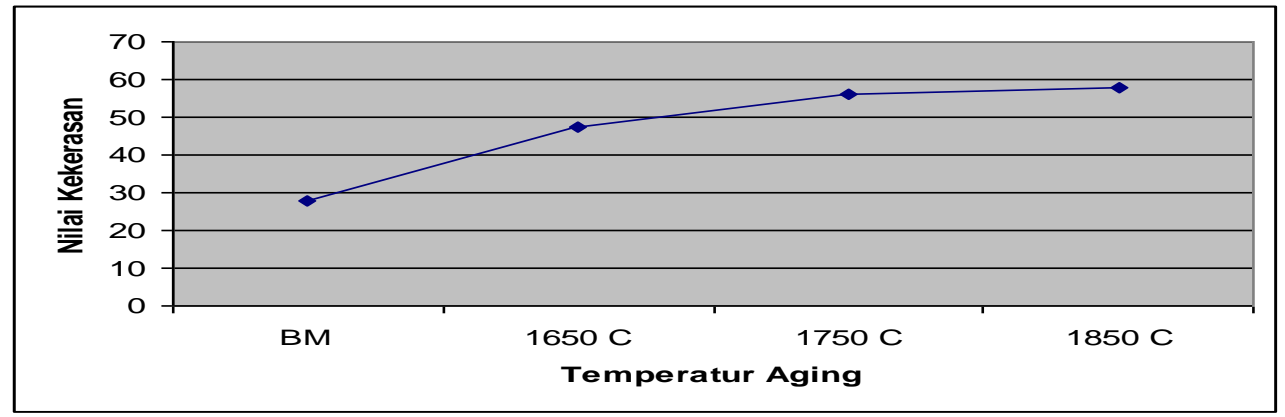

Gambar 7. Grafik Perbandingan Nilai Kekerasan pengaruh Temp Aging

\subsection{Analisa}

Pengujian kekerasan ini dilakukan pada spesimen dasar dan spesimen dengan 3 parameter temperatur Aging yaitu $165{ }^{0} \mathrm{C}, 175{ }^{\circ} \mathrm{C}$ dan 185 ${ }^{0} \mathrm{C}$. Berdasarkan grafik nilai rata-rata diatas dapat dilihat bahwa hasil nilai kekerasan dari spesimen yang mengalami proses aging lebih meningkat dibandingkan dengan nilai kekerasn bahan dasar (base metal), Sedangkan diantara temperatur aging nilai kekerasan yang tertinggi adalah temperatur 185 ${ }^{0} \mathrm{C}$.

Hasil nilai rata-rata kekerasan untuk temperatur aging $165{ }^{\circ} \mathrm{C}$ sebesar 47,6 HRE, ini nilai terendah diantara temperatur aging $175{ }^{\circ} \mathrm{C}$ dengan nilai kekerasan rata-rata sebesar 56,2 HRE dan dan temperatur aging $185{ }^{0} \mathrm{C}$ dengan nilai kekerasan rata-rata sebesar 58 HRE. Rendahnya nialai kekerasan pada temperatur $165{ }^{0} \mathrm{C}$ dipengaruhi pertumbuhan presipitat yang hanya sedikit pada temperatur tersebut sehingga pertumbuhan presipitat tidak seragam pada permukaan. Sedangkan pada temperatur $185{ }^{0} \mathrm{C}$ menghasilkan presipitat lebih banyak sehingga presipitat lebih seragam mengendap pada permukaan.

\subsection{Hasil Pengujian Impact}

Pengujian impact dilakukan pada bahan dasar dan bahan telah mengalami proses aging, kemudian dibentuk seperti pada subbab dimana tiap perlakuan diambil 3 spesimen pengujian untuk mendapatkan nilai 
kekuatan impact yang lebih baik melalui nilai rata-rata dari ketiga spesimen pengujian tersebut.

\subsection{Kekuatan Impact Pada Bahan}

\section{Dasar}

Tabel 7. Hasil Kekuatan Impact Bahan Dasar

\begin{tabular}{|c|c|c|c|c|c|}
\hline \multirow{2}{*}{ No } & \multirow{2}{*}{ Bahan } & \multicolumn{3}{|c|}{ Nilai Kekuatan Impact (Joule) } & Nilai \\
\cline { 3 - 5 } & & Spesimen 1 & Spesimen 2 & Spesimen 3 & Rata-rata \\
\hline 1 & Base Metal & 66 & 67 & 65 & 66.00 \\
\hline
\end{tabular}

Berdasarkan tabel diatas bahan dasar spesimen 1 memiliki energi impak sebesar 60 Joule untuk spesimen 2 kekuatan impact sebesar 67 Joule dan spesimen 3 kekuatan impactnya
Kekuatan impact bahan dasar tiap spesimen dan nilai rata-ratanya ditunjukkan pada tabel 7 yang dapat dilihat dibawah ini : sebesar 65 Joule. Hasil kekuatan impact yang didapat pada ketiga spesimen dasar tersbut dapat digambarkan dalam grafik dibwah ini

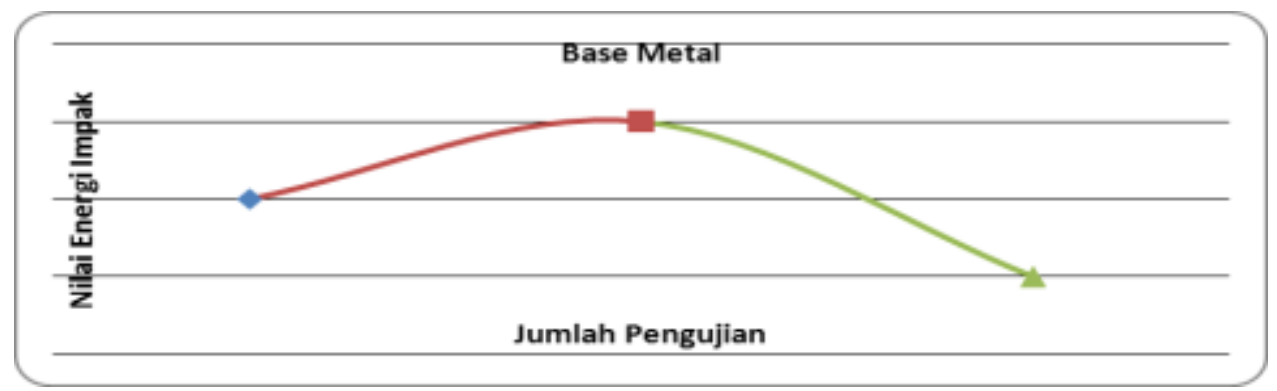

Gambar 8. Grafik Kekuatan Impact Bahan Dasar

3.6 Kekuatan Impact Pada

Temperatur $165^{\circ} \mathrm{C}$

Kekuatan impact Temperatur $165^{\circ} \mathrm{C}$ dan nilai rata-ratanya dari

Tabel 8. Hasil Kekuatan Impact Temperatur $165{ }^{\circ} \mathrm{C}$

\begin{tabular}{|c|c|c|c|c|c|}
\hline \multirow{2}{*}{ No } & \multirow{2}{*}{ Bahan } & \multicolumn{3}{|c|}{ Nilai Kekuatan Impact (Joule) } & \multirow{2}{*}{$\begin{array}{c}\text { Nilai } \\
\text { Rata-rata }\end{array}$} \\
\cline { 3 - 5 } 1 & $\begin{array}{c}\text { Temperatur } \\
165^{\circ} \mathrm{C}\end{array}$ & 95 & 95 & 96 & 95.33 \\
\hline
\end{tabular}


Berdasarkan tabel diatas impactnya sebesar 96 Joule. Hasil Temperatur $165{ }^{0} \mathrm{C}$ spesimen 1 memiliki kekuatan impact sebesar 95 Joule untuk spesimen 2 kekuatan impact yang didapat pada ketiga spesimen Temperatur kekuatan impact sebesar 65 Joule $165{ }^{\circ} \mathrm{C}$ tersbut dapat digambarkan dalam grafik dibawah ini: dan spesimen 3 kekuatan

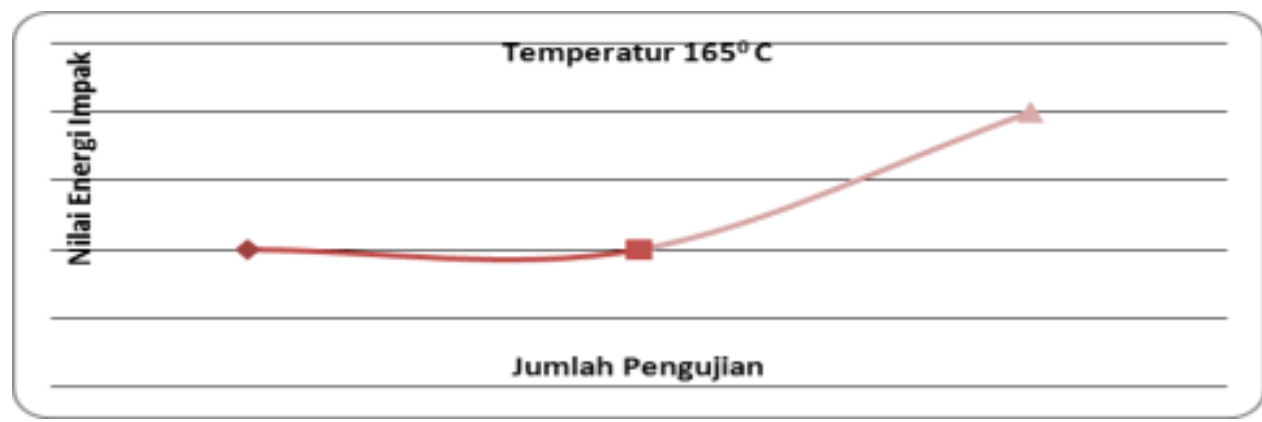

Gambar 9. Grafik Kekuatan Impact Temperatur $165^{\circ} \mathrm{C}$

3.7 Kekuatan Impact Pada

\section{Temperatur $175^{\circ} \mathrm{C}$}

Kekuatan impact Temperatur

$175^{\circ} \mathrm{C}$ dan nilai rata-ratanya dari
3 spesimen yang diujikan dapat

dilihat pada tabel 9 dibawah ini:

Tabel 9. Hasil Kekuatan Impact Temperatur $175{ }^{\circ} \mathrm{C}$

\begin{tabular}{|c|c|c|c|c|c|}
\hline \multirow{2}{*}{ No } & \multirow{2}{*}{ Bahan } & \multicolumn{3}{|c|}{ Nilai Kekuatan Impact (Joule) } & \multirow{2}{*}{ Nilai } \\
\cline { 3 - 5 } & Spesimen 1 & Spesimen 2 & Spesimen 3 & Rata-rata \\
\hline 1 & $\begin{array}{c}\text { Temperatur } \\
175^{\circ} \mathrm{C}\end{array}$ & 97 & 98 & 96 & 97 \\
\hline
\end{tabular}

Berdasarkan tabel diatas Temperatur $175^{\circ} \mathrm{C}$ spesimen 1 memiliki kekuatan impact sebesar 97 Joule untuk spesimen 2 kekuatan impact sebesar 98 Joule dan spesimen 3 kekuatan impactnya sebesar 96 Joule. Hasil kekuatan impact yang didapat pada ketiga spesimen Temperatur $175^{\circ} \mathrm{C}$ tersbut dapat digambarkan dalam grafik dibawah ini : 


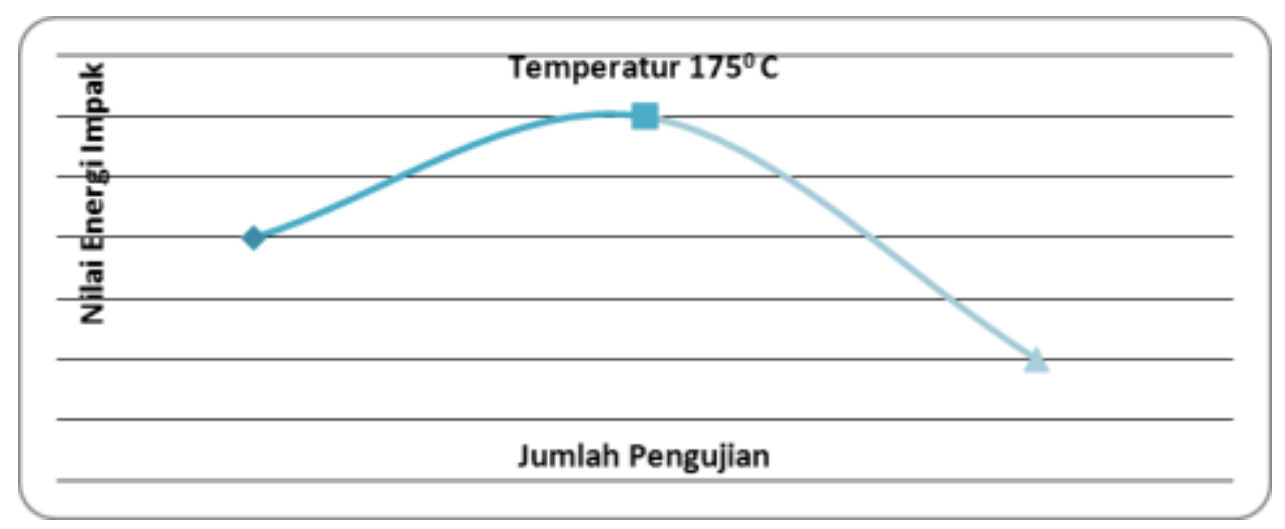

\section{Gambar 10. Grafik Kekuatan Impact Temperatur $175^{\circ} \mathrm{C}$}

\subsection{Kekuatan Impact Pada}

\section{Temperatur $185{ }^{\circ} \mathrm{C}$}

Kekuatan impact Temperatur

$185^{\circ} \mathrm{C}$ dan nilai rata-ratanya dari
3 spesimen yang diujikan dapat

dilihat pada tabel 10 dibawah ini :

Tabel 10. Hasil Kekuatan Impact Temperatur $185{ }^{\circ} \mathrm{C}$

\begin{tabular}{|c|c|c|c|c|c|}
\hline \multirow{2}{*}{ No } & \multirow{2}{*}{ Bahan } & \multicolumn{3}{|c|}{ Nilai Kekuatan Impact (Joule) } & \multirow{2}{*}{$\begin{array}{c}\text { Nilai } \\
\text { Rata-rata }\end{array}$} \\
\cline { 3 - 5 } 1 & $\begin{array}{c}\text { Temperatur } \\
185^{\circ} \mathrm{C}\end{array}$ & 79 & 77 & 80 & 78.67 \\
\hline
\end{tabular}

Berdasarkan tabel diatas Temperatur $185^{\circ} \mathrm{C}$ spesimen 1 memiliki kekuatan impact sebesar 79 Joule untuk spesimen 2 kekuatan impact sebesar 77 Joule dan spesimen 3 kekuatan impactnya sebesar 80 Joule. Hasil kekuatan impact yang didapat pada ketiga spesimen Temperatur $185^{0} \quad \mathrm{C}$ tersebut dapat digambarkan dalam grafik dibawah ini:

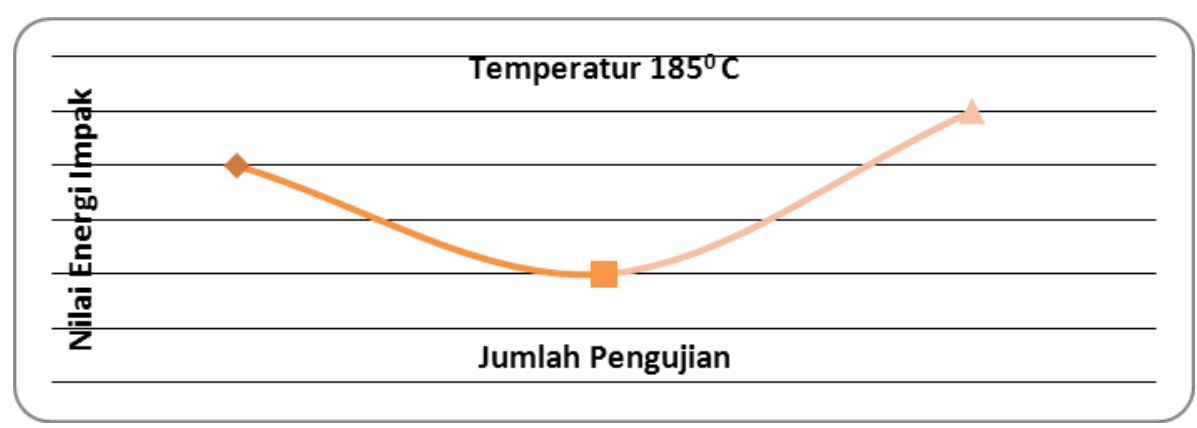

Gambar 11. Grafik Kekuatan Impact Temperatur $185^{\circ} \mathrm{C}$ 
Berdasarkan hasil kekuatan kekuatan impact dari pengaruh impact setiap bahan dan nilai rataproses aging pada paduan rata yang dapat, dibuat table alumunium seri 6069, yang dapat keseluruhan dan grafik guna dilihat dibawah ini:

menggambarkan perubahan

Tabel 11. Hasil Pengujian Kekuatan Impact

\begin{tabular}{|c|l|c|c|c|c|}
\hline \multirow{2}{*}{ No } & \multirow{2}{*}{ Bahan } & \multicolumn{3}{|c|}{ Nilai Kekuatan Impact (Joule) } & \multirow{2}{*}{\begin{tabular}{c} 
Nilai \\
\cline { 3 - 5 }
\end{tabular}} \\
\cline { 2 - 5 } & & Spesimen 1 & Spesimen 2 & Spesimen 3 & Rata-rata \\
\hline 1 & Base Metal & 66 & 67 & 65 & 66.00 \\
\hline 2 & Temperatur $165^{\circ} \mathrm{C}$ & 95 & 95 & 96 & 95.33 \\
\hline 3 & Temperatur $175^{\circ} \mathrm{C}$ & 97 & 98 & 96 & 97 \\
\hline 4 & Temperatur $185^{\circ} \mathrm{C}$ & 79 & 77 & 80 & 78.67 \\
\hline
\end{tabular}

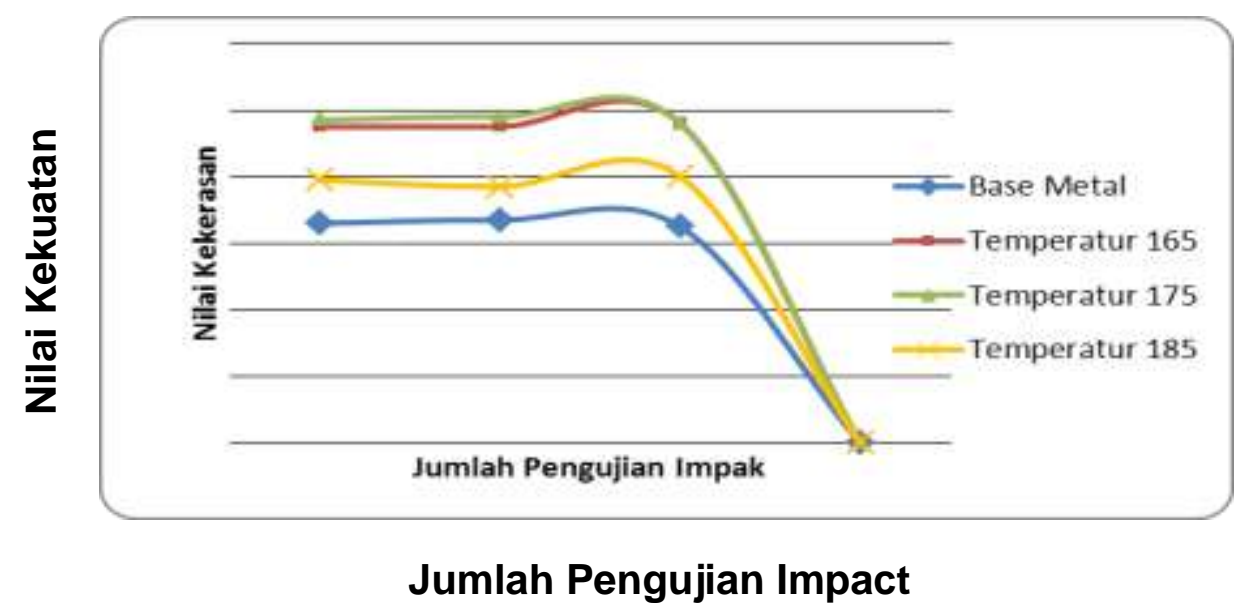

Gambar 12 . Grafik Perbandingan Nilai Kekuatan Impact Material Uji

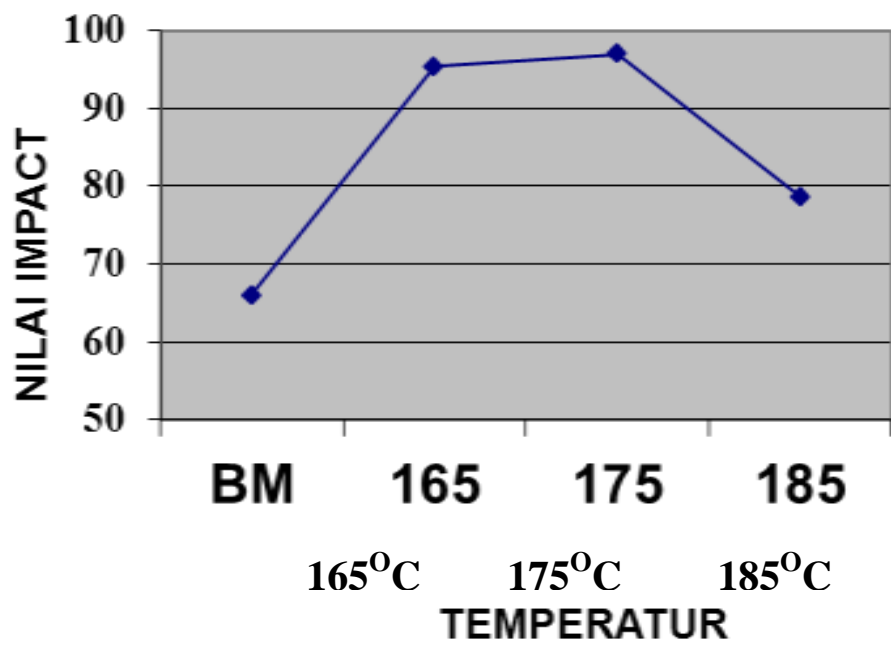

Gambar 13. Grafik Perbandingan Nilai Kekuatan Impact Pengaruh temp Aging 
3.9 Analisa Kekuatan Impact

Dari grafik bias dilihat bahwa energi impak mengalami peningkatan akibat pengaruh proses aging dimana kekuatan impact base metal sebesar 65 Joule sedang untuk spesimen yang mengalami proses aging lebih besar diatas kekuatan impact base metal, temperatur $165 \quad{ }^{0} \mathrm{C}$ memiliki kekuatan impact sebesar 95.33 Joule, untuk temperature $175^{\circ} \mathrm{C}$ kekuatan impact spesar 97 Joule dan temperatur $185{ }^{0} \mathrm{C}$ sebesar 78.67 Joule.

Pada parameter temperatur aging kekuatan impact yang terbesar terdapat pada temperatur $175{ }^{\circ} \mathrm{C}$ sedangkan kekuatan impact yang terendah terdapat pada temperatur $185{ }^{0} \mathrm{C}$. Hal ini dikarenakan peningkatan sifat getas pada material akibat pengaruh temperatur $185{ }^{0} \mathrm{C}$ sehingga kekuatan impact menurun dibandingkan dengan material yang mengalami pengaruh temperature $\quad 165 \quad{ }^{0} \mathrm{C}$ dan temperature $175^{\circ} \mathrm{C}$.

\subsection{Hasil Pengujian Struktur} Mikro
Pengambilan gambar struktur mikro ini dilakukan dengan pembesaran160X, bertujuan untuk melihat terbentuknya presipitat pada setiap parameter yang diuji, sehingga nantinya dapat dilihat parameter mana yang mencapai nilai optimum. pada kondisi awal presipitat yang terdapat sangatlah sedikit akan tetapi sejalan dengan peningkatan temperatur presipitat akan semakin banyak terbebtuk. Peningkatan presipitat tidak secara terus menerus akan tetapi ketika temperatur optimal didapat maka jumlah distribusi presipitat akan menurun. Inilah yang mendasari bahwa proses presipitat tidak selalu mencapai nilai optimum ketika temperatur terbesar.

Hasil dari pengujian ini belum memperlihatkan presipitat yang akan diamati. Hal inidisebabkan keterbatasan alat untuk menujukkan presipitat yang terjadi Struktur mikro yang didapat hanya memperlihatkan bentuk dan batasan struktur mikro pada paduan alumunium.

\section{KESIMPULAN}

Berdasarkan pengujian yang telah dilakukan pada alumunium paduan 
seri 6069, maka dapat diambil

kesimpulan sebagai berikut :

1. Proses aging dapat meningkatkan nilai kekerasan pada alumunium paduan seri 6069, dimana peningkatan maksimum terdapat pada material yang mengalami proses aging dengan temperatur $185^{\circ} \mathrm{C}$.

2. Proses aging juga meningkatkan nilai kekuatan impact pada alumunium paduan seri 6069, dimana peningkatan maksimum kekuatan impact terdapat pada material yang mengalami proses aging dengan temperatur $175^{\circ} \mathrm{C}$

3. Temperature $175^{\circ} \mathrm{C}$ merupakan temperatur optimum untuk meningkatan nilai kekuatan impact, bila melebihi temperature tersebut akan mengalami penurunan kekuatan impact, seperti yang terdapat pada temperature $185^{\circ} \mathrm{C}$.

\section{DAFTAR PUSTAKA}

Annual Book. JIS (Japan International Standar).ASM HANDBOOK, Propertias and selection: Nonferrous Alloys and Special Purpose Material. Volume 2.

Gere dan Timoshenko, 1984, "Mekanika Bahan". Edisi Keempat. Erlangga. Jakarta

Malahayati Universitas, 1998. Pedoman Penulisan Karya Ilmiah,Universitas Malahayati, Bandar Lampung

Mat Web. 2005. "Material Properti data". http://www.MatWeb.com

Muryana, M dan Hono, K. 2002. "The Effect Of Aging On The Clustering And Precipitation Process In AlMg-Si Alloys". Japan.

Timings, R.L. 1998. "Enggeniring Material Technology". Edisi Kedua. Longman. England

Van Vlack, Lawrence H. 1992. "Ilmu dan Teknologi Bahan". Edisi Kelima. Erlangga. Jakarta

W, Borth.G.L.J. Van Vliet. 1984. "Bahan-bahan I". Erlangga. Jakarta 